\title{
PERANAN BALAS JASA DAN INSENTIF TERHADAP MOTIVASI KERJA PADA PT. SONY GEMERLANG MEDAN
}

\author{
Oleh: \\ Sarman Sinaga \\ Universitas Darma Agung Medan \\ E-mail: \\ sarmansinaga17@mail.com
}

\begin{abstract}
PT. Sony Gemerlang Medan is one of the companies engaged in shoe production. The company motivates employees by providing remuneration in the form of basic salary, incentives, benefits, welfare facilities by taking into account the level of education and work tenure of employees, providing time off for employees to overcome fatigue and boredom of work, promoting workforce that achieves to a higher level, rules are set jointly between superiors and subordinates and the existence of a working group and superiors trying to understand the needs and desires of subordinates. Shoe production in 2012 was 1,350 pairs of shoes and in 2013 it dropped to 1,265 pairs of shoes. This shows that employee motivation has decreased. Based on the description, the research problem is formulated as follows: "Does the Reply To Services And Incentives Have The Role Of Work Motivation At PT. Sony Bright Medan? ". This study aims to determine and analyze the dominant factors affecting work motivation at PT. Sony Bright Medan. The benefits of research are providing input to companies in the form of factors that are most dominant affecting work motivation. Data collection techniques used were questionnaires. The data analysis technique used is factor analysis. Repayments and incentives mean not only in financial form. Direct financial forms are wages, salaries, commissions, and bonuses. While the indirect form of insurance, social assistance, leave, pension, training, and so on. Besides the non-financial form of the elements of the type of work and work environment. The form of work element includes responsibility, attention and appreciation from the leadership, while the form of work environment is in the form of a comfortable working condition, distribution of work distribution, and company policy. The most dominant factors influencing work motivation include: incentives, work fatigue, status, transport money, applicable regulations, benefits, satisfaction, personal maturity, good supervision, appreciation for performance and work groups. The advice given to management is that the company should add incentives to employees who excel, pay attention to the work environment, clarify employment status, add transportation money, applicable regulations, increase the types of benefits, increase employee satisfaction, increase personal maturity, add good supervision, appreciation for achievements and enhance collaboration between work groups.
\end{abstract}

Keywords: remuneration, incentives and motivation

PT. Sony Gemerlang Medan merupakan salah satu perusahaan yang bergerak di bidang produksi sepatu. Perusahaan memotivasi karyawan dengan memberikan balas jasa berupa gaji pokok, insentif, tunjangan, fasilitas kesejahteraan dengan memperhatikan tingkat pendidikan dan masa kerja karyawan, memberikan waktu istirahat bagi para karyawan untuk mengatasi kelelahan dan kebosanan kerja, mempromosikan tenaga kerja yang berprestasi ke jenjang yang lebih tinggi, peraturan ditetapkan bersama antara atasan dengan bawahan dan adanya kelompok kerja serta atasan berusaha memahami kebutuhan dan keinginan bawahan. Produksi sepatu pada tahun 2012 sebanyak 1.350 pasang sepatu dan tahun 2013 turun menjadi 1.265 pasang sepatu. Hal ini menunjukkan bahwa motivasi kerja karyawan menurun. Berdasarkan uraian tersebut, dirumuskan masalah penelitian adalah :"Apakah Balas Jasa Dan Insentif Mempunyai Peranan Terhadap Motivasi Kerja Pada PT. Sony Gemerlang Medan?". Penelitian ini bertujuan untuk mengetahui dan menganalisis faktor - faktor yang dominan mempengaruhi motivasi kerja pada PT. Sony Gemerlang Medan. Manfaat penelitian adalah memberikan bahan masukan kepada perusahaan berupa faktor - faktor yang paling dominan mempengaruhi motivasi kerja. Teknik pengumpulan data yang digunakan adalah menggunakan kuesioner. Teknik analisis data yang digunakan adalah analisis faktor. Balas jasa dan Insentif mengandung arti tidak sekedar hanya dalam bentuk bentuk finansial saja. Bentuk finansial langsung berupa upah,gaji, komisi, dan bonus. Sementara yang tidak langsung berupa asuransi, bantuan sosial, uang cuti, uang pensiun, pelatihan, dan sebagainya. Selain itu bentuk bukan finansial berupa unsur-unsur jenis pekerjaan dan lingkungan pekerjaan. Bentuk unsur pekerjaan meliputi tanggung jawab, perhatian dan penghargaan dari pimpinan, sementara bentuk lingkungan pekerjaan berupa kenyamanan kondisi kerja, distribusi pembagian kerja, dan kebijakan perusahaan. Faktor - faktor yang paling dominan berpengaruh terhadap motivasi kerja meliputi : insentif, kelelahan bekerja, status, uang transport, peraturan yang berlaku, tunjangan, kepuasan, kematangan pribadi, supervise yang baik, penghargaan atas prestasi dankelompok kerja. Saran yang diberikan kepada pihak manajemen adalah, sebaiknya perusahaan 
menambah insentif kepada karyawan yang berprestasi, memperhatikan lingkungan kerja, memperjelas status kepegawaian, menambah uang transport, peraturan yang berlaku, menambah jenis tunjangan, meningkatkan kepuasan karyawan, meningkatkan kematangan pribadi, menambah supervise yang baik, penghargaan atas prestasi dan meningkatkan kerjasama antar kelompok kerja.

Kata kunci : balas jasa, Insentif dan Motivasi

\section{PENDAHULUAN}

\section{Latar Belakang}

Sumber daya manusia merupakan salah satu faktor utama yang menentukan berhasil tidaknya suatu perusahaan untuk mencapai tujuannya. Perusahaan perlu mengarahkan, membina, mendorong dan mengelola sumber daya manusia yang berpotensi. Potensi yang dimiliki karyawan harus dimotivasi dengan memenuhi keinginan - keinginan karyawan.

Setiap karyawan akan melakukan pekerjaan yang dibebankan kepadanya dengan baik dan benar sesuai dengan yang diinginkan, bila mempunyai dorongan (motivasi) untuk bekerja dengan baik. Memotivasi bawahan adalah salah satu tugas dari seseorang pemimpin, sehingga bawahannya bisa bekerja sesuai dengan pengarahan yang diberikan. Peningkatan prestasi kerja karyawan memerlukan pemberian dorongan agar mereka mau bekerja dan mau berbuat seperti yang diperintahkan oleh atasannya. Peranan yang penting bagi prestasi karyawan adalah motivasi.

Motivasi merupakan keadaan pribadi seseorang yang mendorong keinginan individu untuk melakukan kegiatan tertentu guna mencapai suatu tujuan akhir berupa kepuasan kerja. Motivasi terdiri dari dua faktor, yaitu: motivators dan hygienes. Motivators atau intrinsic factors seperti achievement dan recognition, menghasilkan kepuasan kerja, sedangkan hygienes atau extrinsicfactors seperti pay dan job security, menghasilkan ketidakpuasan kerja.

Faktor -faktor yang mempengaruhi motivasi kerja karyawan meliputi: tujuan, tantangan, keakraban, tanggung jawab dan kepemimpinan.

Kunci keberhasilan suatu perusahaaan untuk mencapai tujuannya adalah motivasi kerja karyawan, karena jika karyawan memiliki motivasi kerja yang baik, maka semangat kerja semakin meningkat sehingga prestasi kerja juga semakin meningkat.

PT. Sony Gemerlang Medan merupakan salah satu perusahaan yang bergerak dibidang produksi sepatu. Perusahaan memotivasi karyawan dengan memberikan balas jasa berupa gaji pokok, insentif, tunjangan, fasilitas kesejahteraan dengan memperhatikan tingkat pendidikan dan masa kerja karyawan, memberikan waktu istirahat bagi para karyawan untuk mengatasi kelelahan dan kebosanan kerja, mempromosikan tenaga kerja yang berprestasi ke jenjang yang lebih tinggi, peraturan ditetapkan bersama antara atasan dengan bawahan dan adanya kelompok kerja serta atasan berusaha memahami kebutuhan dan keinginan bawahan.

Motivasi kerja juga dilakukan dengan memberikan sanksi - sanksi bagi para karyawan yang tidak mampu menyelesaikan tugas - tugasnya sesuai waktu yang ditetapkan perusahaan. Sanksi yang diberikan mulai dari peringatan lisan, tulisan, skorsing, penurunan jabatan, penundaan kenaikan gaji berkala dan pemutusan hubungan kerja (PHK). Berat ringannya sanksi yang diberikan oleh atasan kepada bawahan tergantung kesalahan yang dilakukan karyawan.

\section{Perumusan Masalah}

Berdasarkan identifikasi masalah, dirumuskan masalah penelitian sebagai berikut: “Apakah Balas Jasa dan Insentif Mempunyai Peranan Terhadap Motivasi Kerja Pada PT. Sony Gemerlang Medan”.

\section{Hipotesis}

Hipotesis adalah rumusan jawaban sementara terhadap suatu permasalahan yang dimaksud sekaligus sebagai tuntutan sementara dalam penyelidikan untuk mencari jawaban yang sebenarnya. Sesuai dengan permasalahan diatas, penulis mencoba membuat suatu hipotesis atau jawaban sementara dari masalah yang ada dan masih dibuktikan, sehingga dapat diterima atau ditolak.

adalah:

Hipotesis yang penulis dapat simpulkan

"Balas Jasa dan Insentif Belum Mempunyai Peranan Terhadap Motivasi Kerja Pada PT. Sony Gemerlang Medan".

Tujuan dan Manfaat Penelitian

Tujuan Penelitian

1. Untuk membandingkan teori - teori yang diperoleh diperkuliahan dengan keadaan yang ada di lapangan.

2. Untuk mengetahui sejauh mana peran balas jasa dan insentif terhadap motivasi kerja pada perusahaan.

3. Untuk mengetahui bagaimana motivasi yang diberikan perusahaan terhadap para karyawan perusahaan. 


\section{Manfaat Penelitian}

1. Menambah pengetahuan penulis tentang peranan balas jasa dan insentif terhadap motivasi kerja.

2. Sebagai bahan masukan pada perusahaan mengenai balas jasa dan insentif terhadap motivasi kerja karyawan.

3. Sebagai bahan pembanding dan referensi bagi peneliti dimasa yang akan datang.

\section{Metode Pengumpulan Data}

1. Penelitian Kepustakaan (Library Research)

Suatu cara pengumpulan data yang dilakukan berdasarkan uraian-uraian teoritis pada buku-buku, literatur-literatur, majalahmajalah, dan artikel-artikel serta sumbersumber data lain yang terdapat pada kepustakaan. Teori data dan informasi ini dapat dijadikan sebagai dasar bagi pembahasan permasalahan selanjutnya.

\section{Penelitian Lapangan (Field Researh)}

Suatu cara penelitian yang dilakukan langsung dilapangan tempat dapat diperoleh data yang dikumpulkan. Dengan cara ini dapat diperoleh dengan mempergunakan daftar pertanyaan dan wawancara langsung kepada pejabatyang berwenang, melihat langsung ditempat kerja sehingga data yang diperoleh masih relevan dengan dasar pembahasan yang dikemukakan.

\section{Metode Analisis}

Dari penelitian ini diperoleh data dan keterangan mengenai sejarah perusahaan, struktur organisasi, laporan penjualan melalui wawancara dengan pimpinan, kepala bagian dari karyawan di perusahaan tersebut. Metode analisis terdiri dari:

\section{Metode analisis deskriptif}

Yaitu merumuskan dan menafsirkan data yang diperoleh, lalu mengolahnya sehingga memberikan gambaran yang jelas mengenai peranan motivasi dan masalahnya dalam perusahaan.

\section{Metode analisis deduktif}

Yaitu pemikiran untuk menarik kesimpulan berdasarkan teori ilmu pengetahuanyang diterima umum sebagai suatu kebenaran, khususnya teori yang berkaitan dengan motivasi

\section{Uraian Teoritis}

\section{Pengertian Motivasi Kerja}

Motivasi berasal dari kata latin Movere yang berarti dorongan atau menggerakkan. Motivasi (motivation) dalam manajemen hanya ditujukan pada sumber daya manusia umumnya dan bawahan khususnya. Motivasi mempersoalkan bagaimana caranya mengarahkan sumber daya dan potensi bawahan, agar mau bekerja sama secara produktif berhasil mencapai dan mewujudkan tujuan yang telah ditentukan.

Motivasi merupakan salah satu fungsi manajemen di antara fungsi-fungsi manajemen lainnya, maka motivasi merupakan fungsi yang tergolong erat hubungannya dengan unsur manusia, bahkan tidak salah jika dikatakan bahwa masalah motivasi merupakan masalah dalam manajemen atau Managerial HumanProblem. Secara umum motivasi dapat diartikan sebagai suatu dorongan yang membuat orang mau bekerja untuk bertindak.

Motivasi merupakan kegiatan yang melibatkan, menyalurkan dan memelihara perilaku manusia yaitu proses untuk mempengaruhi seseorang untuk melakukan apa yang kita inginkan.

Motivasi biasanya berhubungan erat dengan kesejahteraan dan pada umumnya diidentikkan dengan barang-barang yang berwujud dan dapat dirasa seperti pemberian bonus, insentif, fasilitas-fasilitas lainnya yang diinginkan oleh karyawan disamping promosi yang merupakan motivasi tidak berwujud.

Untuk mendorong dan menggerakkan orang-orang agar bersedia bekerja semaksimal mungkin, perlu diusahakan adanya komunikasi dan peran serta dari semua pihak. Motivasi menuntut agar manajer mengetahui bagaimana memberikan informasi kepada bawahannya, bagaimana ia menyediakan waktunya untuk berusaha memperoleh saran-saran dan rekomendasi mengenai masalah yang dihadapi.

\section{Prinsip-prinsip Motivasi}

Motivasi yang diberikan pada umumnya bersifat material dan non material. Dalam pemberian motivasi, baik yang bersifat material maupun yang bersifat non material harus dapat berlandaskan pada prisip-prinsip motivasi.

Motivasi yang bersifat material biasanya berlandaskan pada prisip-prinsip sebagai berikut :

\section{Adanya jaminan upah/gaji minimum}

Jaminan upah merupakan sutu hal yang harus diperhatikan oleh manajemen. Umumnya para pegawai selalu bekerja untuk memperoleh gaji yang teratur dan menetap, ia tidak mau berada dalam keadaan yang tidak menentu dalam penghasilannya. Selain dari pada itu, gaji/upah minimum dapat menghindarkan pengenaan upah yang tidak wajar bagi pegawai lama yang dipindahkan dari satu jenis pekerjaan ke pekerjaan lainnya.

2. Ketepatan dalam pemberian kompensasi tambahan

Dalam pemberian kompensasi tambahan, ketepatan waktu mempunyai efek psikologis, karena para pekerja tidak menunggu bukti hasilhasil kerja tambahannya. Kegairahan kerjanya dihargai walaupun belum menghasilkan sesuatu yang konkrit. 
3. Sistem motivasi harus dirumuskan dengan hatihati sehingga tidak menimbulkan pengurangan tingkat upah.

Sistem motivasi harus dirumuskan dengan hati-hati sehingga tidak memungkinkan adanya pemotongan atau pengurangan tingkat upah/gaji. Perusahaan akan memberikan kesempatan kepada para karyawan untuk menambah penghasilannya, tetapi jumlahnya tidak melampaui yang seharusnya diterima. Untuk mencapai keefektifan yang maksimal, maka motivasi hendaknya didasarkan atas kebutuhan dan keinginan karyawan dengan melihat pada kemampuan yang dimiliki oleh perusahaan, sehingga diantara keduanya tidak ada yang dirugikan.

4. Sistem motivasi harus dapat menimbulkan kepercayaan diri pada karyawan.

Agar berhasil dengan baik, suatu sistem haruslah dapat menimbulkan kepercayaan karyawan. Sistem tersebut harus sederhana sehingga karyawan dapat menghitung jumlah pendapatannya dan disesuaikan dengan upah/ gaji yang diterimanya. Dengan demikian ia merasa terjamin bahwa perusahaan tidak menggunakan cara yang kompleks untuk mendapatkan keuntungan darinya. Sistem penggajian/upah yang menimbulkan kecurigaan bagi para karyawan adalah merupakan suatu hal yang sangat buruk, dalam hal ini perusahaan lebih baik tidak menggunakan sistem sama sekali.

Motivasi yang bersifat non material pada dasarnya berlandaskan pada :

1. Penghargaan atas pekarjaan yang baik.

2. Sikap manajemen harus meluas kebawah dalam mata rantai yang tidak terputusputus.

3. Kontak pribadi yang harus sering dikembangkan antara pimpinan dengan bawahan.

4. Kepentingan dari individu dan kelompok harus dipenuhi.

5. Loyalitas pribadi antara manajer dan eksekutif harus dipelihara.

\section{Tujuan Motivasi}

Proses motivasi perlu untuk menyatakan tujuan organisasi dimana motivasi merupakan akibat dari hasil yang ingin dicapai oleh seseorang dan perkiraan yang bersangkutan bahwa tindakannya akan mengarah kepada tujuan itu.

Tujuan motivasi adalah sebagai berikut :

a) Meningkatkan moral dan kepuasan kerja karyawan.

b) Meningkatkan produktifitas kerja karyawan.

c) Meningkatkan kestabilan karyawan perusahaan. d) Meningkatkan kedisiplinan karyawan perusahaan.

e) Menciptakan suasana dan hubungan kerja yang baik.

f) Menciptakan loyalitas, kreatifitas dan partisipasi karyawan.

g) Meningkatkan tingkat kesejahteraan karyawan.

h) Mempertinggi rasa tanggung jawab karyawan terhadap tugas - tugasnya.

i) Meningkatkan efisiensi penggunaan alat alat.

\section{Bentuk - Bentuk Motivasi}

Pada garis besarnya, motivasi yang diberikan dibagi menjadi dua bagian, yaitu

1. Motivasi negative

2. Motivasi positif

Motivasi yang dapat diberikan kepada bawahan dapat berupa materialincentive dan non material incentive. Material incentive merupakan motivasi yang bersifat material sebagai imbalan prestasi yang diberikan oleh karyawan. Materialincentive berbentuk uang dan barang- barang. Non material incentive merupakan motivasi yang tidak berbentuk materi.

\section{Faktor - faktor yang Mempengaruhi Motivasi} Kerja

Motivasi merupakan salah satu faktor yang mempengaruhi produktifitas kerja, untuk itu akan di bahas secara keseluruhan faktor - faktor yang mempengaruhi produktifitas kerja tersebut. Untuk dapat menjamin kebehasilan usaha dalam meningkatkan produktifitas dalam suatu perusahaan maka faktor - faktor yang penting harus diperhatikan agar produktifitasdapat dicapai antara lain adalah sebagai berikut :

1. Keadaan fisik (kesehatan, gizi)

2. Pendidikan dan keterampilan

3. Lingkungan kerja

4. Perumahan

5. Etos kerja

6. Faktor manajerial

7. Peralatan yang digunakan

Menurut Sinaga D, (2018) faktor - faktor yang mempengaruhi motivasi kerja seseorang adalah faktor internal dan faktor eksternal.

a) Faktor internal (intrinsik) meliputi:

1. Persepsi seseorang mengenai dirinya

Persepsi seseorang mengenai dirinya merupakan pandangan seseorang mengenai kemampuan dan keterampilannya. Apabila seseorang mempresepsikan bahwa dia memiliki kemampuan dan keterampilan, hal ini akan memotivasinya untuk bekerja lebih baik. Dalam menumbuhkan persepsi 
tertentu, karyawan biasanya menggunakan empat hal sebagai pembanding, yaitu:

- Harapannya berdasarkan kualifikasi imbalan yang dianggapnya layak diterima berdasarkan kualifikasi diri sendiri seperti pendidikan, sifat pekerjaan dan pengalamannya.

- Imbalan yang diterima oleh orang lain dalam organisasi yang kualifikasi dan sifat pekarjaannya relatif sama dengan yang bersangkutan sendiri.

- Imbalan yang diterima oleh karyawan lain di perusahaan lain di kawasan yang sama serta melakukan kegiatan sejenis.

- Peraturan yang berlaku mengenai jumlah dan jenis imbalan yang merupakan hak para karyawan.

2. Keinginan dan harapan pribadi

Keinginan dan harapan pribadi, yaitu tujuan yang ingin dicapai seseorang dalam bekerja. Dalam hal ini, karyawan menginginkan agar prestasi kerjanya diperhatikan oleh atasan dengan memberikan peluang untuk menduduki jabatan yang lebih tinggi. Motivasi merupakan akibat dari suatu hasil yang ingin dicapai seseorang dan perkiraan yang bersangkutan bahwa tindakannya mengarah ke hasil yang diinginkan. Jika seseorang menginginkan suatu dan harapan untuk memperoleh sesutu itu cukup besar, maka ia akan terdorong untuk memperoleh hal yang diinginkannya itu. Sebaliknya, jika harapan memperoleh yang diinginkannya itu tipis, motivasinya pun akan rendah.

\section{Kebutuhan}

Teori Hirarki Kebutuhan dari Maslow (dalam Daft, 2003:95) menyatakan bahwa manusia dimotivasi oleh berbagai kebutuhan dan kebutuhan ini dalam urutan hirarki. Maslowmengidentifikasi dalam urutan yang semakin meningkat:

- Kebutuhan fisiologi adalah kebutuhan fisik manusia paling dasar, termasuk pangan, air, gaji pokok, jaminan kelangsungan hidup dan seks.

- Kebutuhan keamanan adalah kebutuhan untuk keselamatan dan jaminan lingkungan fisik serta emosional dan kebebasan dari ancaman.

- Kebutuhan rasa aman, yaitu hasrat untuk diterima sesama, mempunyai ikatan pertemanan, menjadi bagian dari sebuah kelompok, dan dicintai.

- Kebutuhan penghargaan, kebutuhan ini berhubungan dengan hasrat untuk memiliki kesan positif dan menerima perhatian, pengakuan dan apresiasi dari orang lain.
- Kebutuhan aktualisasi diri. Hal ini menekankan pada potensi, peningkatan kompetensi seseorang, dan menjadi orang yang lebih baik.

\section{Kepuasan kerja}

Kepuasan kerja adalah emosional yang menyenangkan dan tidak menyenangkan dengan mana karyawan memandang pekerjaan mereka. Kepuasan kerja tergantung pada tingkat perolehan intrinsik dan ekstrinsik dan tergantung dari pandangan pemegang pekerjaan terhadap perolehan tersebut. Unsur kognisi dan perilaku orang terhadap pekerjaannya dianggap sebagai unsur - unsur yang dikandung dalam kepuasan kerja. Sikap karyawan yang dijadikan sebagai salah satu ukuran kepuasan kerja lebih dimaksudkan sebagai pandangan pemegang pekerjaan terhadap perolehan intrinsik dan ekstinsik. Sedangkan ukuran lain meliputi: pergantian shif karyawan, keterlambatan dan keluhan dapat dimasukkan dalam kategori perilaku. Sedangkan unsur afeksi sikap belum terpenuhi oleh ukuran-ukuran yang mereka ajukan.

\section{Prestasi kerja}

Prestasi kerja adalah hasil kerja secara kualitas dan kuantitas yang dicapai seseorang karyawan dalam melaksanakan tugasnya sesuai dengan tanggung jawab yang diberikan kepadanya. Prestasi kerja karyawan turut menentukan keberhasilan suatu organisasi dalam mencapai tujuannya. Prestasi kerja yang distandarkan akan tercapai apabila didukukng oleh kemampuan, keinginan, upaya kerja dan dukungan organisasi.

b) Faktor eksternal (ekstrinsik) yang turut mempengaruhi motivasi seseorang:

1. Jenis dan sifat pekerjaan

Jenis pekerjaan berkaitan dengan bidang pekerjaan yang ditempatkan seseorang dalam organisasi. Jenis pekerjaan ini seperti bidang pemasaran, bidang produksi, bidang pembukuan dan keuangan, bidang personalia dan teknik dan lain sebagainya. Sifat pekerjaan berhubungan dengan resiko yang mungkin ditimbulkan oleh pekerjaan tersebut.

2. Kelompok kerja

Kelompok kerja, yaitu bagian-bagian yang ditugaskan untuk menyelesaikan suatu pekerjaan tertentu. Bagian tersebut, misalnya bagian pemasaran, bagian produksi, bagian pembukuan dan keuangan, bagian personalia, bagian teknik, dan lain sebagainya. Untuk mencapai tujuan organisasi, maka setiap individu 
yang bergabung dalam kelompok kerja harus bekerja sama dan saling membantu satu sama lain.

3. Situasi lingkungan kerja

Lingkungan kerja yang aman dan nyaman dilakukan dengan menjaga kebersihan ruang kerja karyawan. Jika lingkungan kerja aman dan nyaman, maka motivasi kerja meningkat dan sebaliknya, jika lingkungan kerja kurang menyenangkan maka motivasi kerja turun.

4. Sistem imbalan

Sistem imbalan berkaitan dengan balas jasa yang diberikannya demi pencapaian tujuan organisasi. Jenis-jenis imbalan adalah gaji pokok, insentif, tunjangan dan fasilitas kesejahteraan. Gaji produk, yaitu kompensasi dasar yang diterima oleh pegawai biasanya sebagai gaji atau upah. Insentif, yaitu balas jasa yang diterima karyawan selain gaji pokok yang dihitung berdasarkan jam kerja lembur dan prestasi kerja. Tunjangan, yaitu imbalan tidak langsung seperti asuransi kesehatan, atau uang pensiun diberikan kepada pegawai sebagai bagian dari keanggotaannya di organisasi.

Lebih lanjut, Saydam menyatakan faktor faktor yang mempengaruhi motivasi kerja adalah :

a) Faktor intern yang terdapat pada diri si karyawan itu sendiri. Faktor intern meliputi:

1. Kematangan pribadi

Kematangan pribadi seseorang amat berpengaruh pada motivasi dalam melaksanakan pekerjaan. Orang yang egois dan manja, biasanya akan kurang peka dalam menerima motivasi yang diberikan, sehingga agak susah untuk dapat bekerja sama dalam membuat prestasi kerja.

2. Tingkat pendidikan

Tingkat pendidikan yang dilalui seseorang berpengaruh terhadap motivasi kerja seseorang. Karyawan yang mempunyai pendidikan lebih tinggi biasanya akan lebih mudah termotivasi, karena ia sudah mempunyai pengetahuan dan wawasan yang lebih luas dibandingkan dengan karyawan yang berpendidikan lebih rendah.

3. Keinginan dan harapan pribadi

Seseorang mau bekerja keras bila ada keinginan dan harapan pribadi yang hendak diwujudkan menjadi kenyataan. Ia akan dapat bekerja lebih optimal bila keinginan dan harapannya itu dapat dipenuhi. Misalnya, orang yang lebih bergairah bekerja bila keinginannya untuk promosi jabatan mendapat tanggapan baik dari perusahaan. Ia akan lebih rajin bila harapan pengembangan karier untuk masa datang lebih terjamin dan terarah.
4. Kebutuhan

Menurut teori motivasi kebutuhan yang dikemukakan oleh ahli, bahwa usaha untuk memenuhi kebutuhan merupakan faktor yang mendominasi seseorang untuk mau bekerja dengan baik. Kebutuhan dianggap berbanding lurus dengan motivasi, Makin besar kebutuhan seseorang, makin besar pula motivasi yang bersangkutan untuk bekerja keras.

5. Kelelahan dan kebosanan

Kelelahan dan kebosanan merupakan faktor yang mempengaruhi semangat dan kegairahan kerja seseorang. Berkurangnya semangat kerja akan mengurangi tingkat prestasi yang dapat dicapai seseorang dalam melakukan pekerjaan.

6. Kepuasan

Perusahaaan yang baik terdapat komunikasi dua arah, dari atas berupa informasi tentang perkembangan perusahaan dan dari bawah berupa laporan hasil pekerjaan. Informasi dari bawah oleh pimpinan sebagai dasar pengambilan keputusan, sedangkan dari atasan perlu bagi karyawan untuk mengetahui kemampuan kerja mereka sudah sampai sejauh mana.

b) Faktor ekstern yang berasal dari luar diri karyawan.

Faktor eksternal yang mempengaruhi motivasi kerja mencakup:

1) Lingkungan kerja yang menyenangkan

Lingkungan pekerjaan adalah keseluruhan sarana dan prasarana kerja yang ada disekitar karyawan yang sedang melakukan pekerjaan yang dapat mempengaruhi pelaksanaan pekerjaan itu sendiri. Lingkungan kerja meliputi: tempat kerja, ketenangan, termasuk juga kebersihan, pencahayaan, fasilitas dan peralatan kerja, hubungan antara orang-orang yang ada di tempat kerja.

2) Kompensasi yang memadai

Kompensasi merupakan sumber penghasilan utama bagi para karyawan untuk menghidupi diri beserta keluarganya. Kompensasi yang memadai merupakan alat motivasi yang paling ampuh bagi perusahaan untuk mendorong para karyawan bekerja dengan baik.

3) Supervisi yang baik

Fungsi supervisi dalam suatu pekerjaan adalah memberikan pengarahan, bimbingan kerja kepada para karyawan, agar mereka dapat melaksanakan pekerjaan dengan baik tanpa membuat kesalahan. Dengan demikian, posisi supervisi amat dekat dengan para karyawan, dan selalu menghadapi karyawan dalam melaksanakan tugas sehari-hari.

4) Adanya penghargaan atas prestasi 
Setiap orang akan mau bekerja matimatian mengorbankan apa yang ada pada dirinya untuk perusahaan, kalau yang bersangkutan merasa ada jaminan karir yang jelas dalam melakukan pekerjaan. Mereka bekerja bukannya untuk hari ini saja, tetapi mereka berharap akan dapat bekerja sampai tua cukup dalam satu perusahaan saja.

5) Status dan tanggung jawab

Status atau kedudukan dalam jabatan tertentu merupakan dambaan setiap karyawan dalam bekerja. Mereka bukan hanya mengharapkan kompensasi semata, tetapi juga berharap akan dapat kesempatan menduduki jabatan dalam perusahaan. Status dan kedudukan merupakan dorongan untuk memenuhi kebutuhan sense of achievement dalam tugas sehari-hari.

6) Peraturan yang berlaku

Bagi suatu perusahaan yang besar, biasanya sudah ditetapkan sistem dan prosedur kerja yang harus dipatuhi oleh seluruh karyawan. Sistem dan prosedur kerja ini disebut dengan peraturan yang berlaku dan bersifat mengatur dan melindungi para karyawan.

\section{DEKSKRIPSI PT SONY GEMERLANG MEDAN}

PT. Sony Gemerlang Medan merupakan salah satu perusahaan yang bergerak di bidang produksi sepatu. Perusahaan ini berkedudukan di Medan yang didirikan pada tanggal 19 Maret 1985 dengan Akte No. 74 tambahan No. 231/1078 yang terakhir dirubah pada tanggal 25 Oktober 1994 dengan No. 116. Kantor pusat perusahaan ini berada di Jl. Binjai km 2 Medan.

Pada awalnya, PT. Sony Gemerlang Medan merupakan sebagai distributor sepatu saja. Pada saat ini, PT. Sony Gemerlang Medan telah berkembang menjadi salah satu perusahaan produksi sepatu yang cukup benefit di Medan. Kegiatan perusahaan ini melibatkan tenaga kerja dan peralatan. Pihak-pihak yang terkait di dalam perusahaan adalah tenaga kerja atau buruh dan pihak keamanan.

Pelaksanan kegiatan produksi sepatu ini harus ada perjanjian kontrak dengan para distributor sepatu. Syarat - syarat dalam isi kontrak kerja adalah jumlah sepatu yang di pesan, waktu yang disepakati untuk memproduksi sepatu tersebut, toleransi bila terjadi suatu masalah dalam pekerjaan.

PT. Sony Gemerlang Medan melebihi batasan-batasan industri untuk dikembangkan dengan bermacam - macam aktivitas perdagangan lebih lanjut bisnis sandal. Networking dan pengalaman perlu diuji untuk mendukung produktivitas sandal tersebut.
Fasilitas PT. Sony Gemerlang Medan memiliki persediaan seperti ruang istirahat, ruang sholat, dan mes untuk para karyawan. Perusahaan ini telah mengekspor barang ke luar kota Medan seperti Jakarta, Surabaya, Kalimantan dan Lampung. Mitra bisnis perusahaan ini meliputi para distributor sepatu yang ada di kota Medan.

Fasilitas yang diberikan perusahaan kepada karyawan meliputi tempat tinggal untuk para karyawan, motor, dan juga jaminan kesehatan.

Pergudangan PT. Sony Gemerlang Medan dibangun diatas area 1 hektar yang terletak di jalan Binjai km 2 Medan. Gudang ini digunakan untuk tempat produksi barang dan tempat penyimpanan barang-barang yang sudah jadi sebelum di salurkan ke berbagai tempat di Medan.

\section{Struktur Organisasi}

Struktur organisasi suatu perusahaan meliputi penentuan kegiatan yang diperlukan untuk mencapai tujuannya, pengelompokan, dan penyerahan tugas-tugas pada bagian-bagian dan pendelegasian wewenang yang diperlukan untuk pelaksanaannya. Struktur organisasi merupakan suatu sarana terhadap keberhasilan suatu perusahaan yang menggambarkan tugas, tanggung jawab dan wewenang masing - masing bagian. Dengan adanya struktur organisasi, dapat menghindari terjadinya kesimpang siuran penyelesaian pekerjaan.

Struktur organisasi PT. Sony Gemerlang Medan berbentuk garis dan staff, dimana atasan memberikan perintah langsung kepada bawahan dan berhak meminta laporan pertanggung jawaban atas penyelesaian tugas-tugasnya. Para staff berfungsi untuk memberikan saran dan nasehat kepada pimpinan atas kebijakan-kebijakan yang ditetapkan oleh perusahaan.

\section{Motivasi Yang Diberikan PT. Sony Gemerlang Medan}

Pemberian motivasi kepada pegawai pada suatu perusahaan sering kali diartikan dengan pemberian gaji/upah yang layak kepada para pegawai yang bertujuan untuk meningkatkan produktivitas para pegawai dan pada gilirannya akan meningkatkan penghasilan tiap pegawai.

Gaji/ upah seringkali diartikan sebagai imbalan yang diterima oleh seorang didalam hubungan kerja baik berupa uang maupun barang melalui suatu perjanjian kerja. Imbalan yang diterima ini akan dipergunakan untuk memenuhi kebutuhan hidup, baik bagi dirinya maupun keluarganya.

Sehubungan dengan fungsi untuk memenuhi kebutuhan hidup maka gaji/ upah yang diterima dapat dipergunakan untuk :

1. Memenuhi kebutuhan yang rendah, artinya gaji/ upah yang diperoleh masih dirasakan kurang bila untuk memenuhi kebutuhan akan makanan, 
perumahan, kesehatan, pendidikan dan lain sebagainya.

2. Memenuhi tingkat hidup minimum atau disebut subsistance level artinya gaji/upah yang diperoleh sudah berada pada tingkat kemampuan untuk memenuhi kebutuhan hidup pada tingkat minimum.

3. Memiliki tingkat hidup yang layak disebut diving wage level, artinya gaji// upah yang diterima sudah cukup untuk hidup secara layak melalui penerimaan gaji tadi.

Pemberian motivasi bertujuan untuk menghasilkanproduktivitas yang tinggi dan ini tidak akan berhasil kalau hanya dengan pemberian gaji yang layak kepada para pegawai, karena pegawai mungkin saja akan lalai dalam melaksanakan tugasnya, maka pemberian motivasi dapat diartikan dengan pemberian sanksi ataupun ancaman kepada pegawai apabila ia bertindak di luar jalur tugas dan tanggung jawab yang diberikan kepadanya.

Oleh karena hal tersebut, PT. Sony Gemerlang Medan dalam melaksanakan motivasi karyawan selain memberikan gaji/upah pokok juga memberikan fasilitas lain seperti :

1. Fasilitas kesehatan

2. Tunjangan hari raya

3. Jaminan keselamatan kerja (ASTEK)

4. Pemberian cuti tahunan

5. Uang makan

Disamping motivasi yang sifatnya memberikan hadiah ataupun fasilitas - fasilitas yang diberikan perusahaan kepada karyawannya, perusahaan juga memberikan motivasi yang sifatnya mengenakan sanksi kepada karyawan apabila tindakan-tindakannya telah menyalahi aturan ataupun disiplin organisasi. Pengenaan sanksi yang diberikan oleh perusahaan kepada para karyawannya terdiri dari tiga tingkatan yaitu :

\section{a. Teguran lisan}

Teguran lisan dilaksanakan oleh atasan kepada para bawahannya tersebut melakukan suatu kesalahan pada saat itu namun kesalahan itu dianggap sebagai kesalahan ringan dan dapat diatasi. Teguran lisan ini hanya mengurangi nilai prestasi kerja karyawan tersebut.

b. Teguran tulisan

Teguran tulisan dilaksanakan apabila salah seorang karyawan masih selalu melakukan kesalahan yang sama padahal sudah selalu mendapat teguran lisan dari atasannya ataupun dikenakan kepada karyawan yang tidak memenuhi target prestasi kerja pada waktu yang telah ditentukan.

\section{c. Pemecatan}

Pemecatan ataupun pemutusan hubungan kerja terutama sekali dikenakan oleh perusahaan kepada karyawannya apabila karyawan tersebut telah nyata-nyata melanggar ketentuan ketentuan ataupun aturan yang ditetapkan oleh perusahaan sehingga dapat berakibat fatal dan merugikan perusahaan. Untukkesalahan tersebut perusahaan langsung mem-PHK karyawan tersebut tanpa pesangon, tetapi untuk keteledoran besar perusahaan memberikan skorsing.

Motivasi lainnya dalam bentuk nonmaterial diberikan dalam bentuk penghargaan kepada karyawan teladan. Yang dipilih dari karyawan masing-masing divisi. Untuk karyawan yang terpilih sebagai karyawan teladan akan diberikan penghargaan berupa piagam dari perusahaan, disamping itu sudah jelas mereka akan diprioritaskan untuk kenaikan jabatan apabila terdapat kesempatan untuk promosi.

Sebaliknya apabila terdapat karyawan yang tidak disiplin akan dikenakan sanksi demosi atau pemberhentian dengan tidak hormat untuk tingkat pelanggaran kedisiplinan yang tidak terlalu berat akan dimutasikan ke posisi yang lebih rendah dari yang di pegang saat ini.

Balas Jasa Dan Insentif Yang Diberikan PT. Sony Gemerlang Medan

a) Gaji/ Upah Karyawan

Gaji pokok yang ditetapkan untuk karyawan sebesar Rp. 30.000. Hal ini sudah cukup memadai yang diperkirakan cukup untuk kebutuhan fisik minimum karyawan. Dari datadata terlihat bahwa perusahaan senantiasa berusaha meningkatkan taraf hidup karyawan dengan peningkatan jumlah gaji dan tunjangan setiap tahunnya. Selain itu sistem memberikan tambahan gaji yang diterapkan oleh perusahaan dapat memotivasi karyawan, hal ini berdasarkan prestasi dan kemampuan yang ditunjukkan oleh karyawan.

b) Uang Lembur

Untuk memotivasi karyawan agar lebih meningkatkan produktivitas perusahaan telah menerapkan sistem pemberian uang lembur seperti yang telah dikemukakan pada bab terdahulu. Sistem pemberian uang lembur yang ditetapkan perusahaan cukup ketat sehingga karyawan harus berusaha mengoptimalkan kemampuannya untuk mendapatkan fasilitas tersebut, sementara karyawan yang memiliki sikap santai tetap kurang termotivasi.

c) Tunjangan Transportasi

Tunjangan transportasi yang diberikan oleh perusahaan kurang memotivasi karyawannya karena jumlahnya kurang mencukupi. Disamping itu karyawan yang belum satu tahun bekerja tidak mendapat tunjangan transport, tentu saja akan 
menimbulkan kesenjangan sosial. Dalam hal ini perusahaan dinilai kurang adil.

d) Fasilitas Kesehatan

Fasilitas kesehatan yang diberikan oleh perusahaan cukup memadai dan sehingga dapat memotivasi karyawannya. Dengan memberikan fasilitas pengobatan gratis akan lebih memotivasi karyawan untuk tetap setia dan loyal kepada perusahaan.

1. Material incentive, yaitu pemberian insentif atau premi atau perangsang yang dapat dinilai dengan uang. Uang merupakan suatu alat motivasi yang berguna untuk memuaskan kebutuhan ekonomi karyawan. Kalau kita bertanya kepada seseorang karyawan mengapa ia bekerja maka jawabannya yang sering diberikan adalah untuk mendapatkan uang. Pengguna uang sebagai alat motivasi terutama berguna untuk memuaskan kebutuhan yang bersifat physiologis.

2. Non material incentive, yaitu segala jenis perangsang atau insentif yang tidak dapat dinilai dengan uang. Umumya pemberian non material dapat berupa fasilitas yang diberikan kepada karyawan yang berprestasi.

\section{ANALISIS DAN EVALUASI \\ Balas Jasa Yang Diterima Karyawan}

Secara umum balas jasa merupakan hak seseorang atas hal-hal yang telah dilakukan atau dikerjakannya. Seberapa besar atau seberapa banyak balas jasa yang diterima seseorang sangat tergantung dari apa yang telah atau akan dikerjakannya, atau sebagaimana disebutkan terdahulu bergantung pada sumbangan seseorang terhadap pencapaian tujuan organisasi. Balas jasa biasanya diberikan dalam bentuk uang atau disebut sebagai balas jasa innatura, dan dalam bentuk kenikmatan (benefits) atau disebut sebagai balas jasa natura. Biasanya ke dua jenis imbalan tersebut merupakan suatu paket, artinya pekerja tidak hanya menerima balas jasa uang saja atau menerima kenikmatan semata. Ada juga beberapa ahli yang menambahkan bahwa ada jenis balas jasa lain, yaitu yang berupa fasilitas.Balas jasa yang berupa uang antara lain adalah : gaji pokok, upah lembur, bonus, tunjangan hari raya, tunjangan daerah tertentu, tunjangan kerja di daerah terpencil, tunjangan makan, tunjangan transportasi, tunjangan anak, tunjangan kesehatan., tunjangan pajak, dsb. Umumnya balas jasa ini berupa uang cash, yang diberikan pada waktu-waktu yang telah ditetapkan, tetapi beberapa tunjangan dari daftar tersebut dapat juga dianggap sebagai kenikmatan. Misalnya tunjangan makan dapat saja diberikan dalam bentuk makan siang ataupun tunjangan kesehatan dalam bentuk fasilitas klinik dan pemeriksaan oleh dokter perusahaan. Sedangkan balas jasa kenikmatan dapat berupa cuti tahunan, cuti sakit, cuti hamil, tunjangan kecelakaan kerja, asuransi, mobil dinas, perumahan dsb.

a) Gaji/ Upah Karyawan

Gaji pokok yang ditetapkan untuk karyawan sebesar Rp. 30.000. Hal ini sudah cukup memadai yang diperkirakan cukup untuk kebutuhan fisik minimum karyawan. Dari datadata terlihat bahwa perusahaan senantiasa berusaha meningkatkan taraf hidup karyawan dengan peningkatan jumlah gaji dan tunjangan setiap tahunnya. Selain itu sistem memberikan tambahan gaji yang diterapkan oleh perusahaan dapat memotivasi karyawan, hal ini berdasarkan prestasi dan kemampuan yang ditunjukkan oleh karyawan.

b) Uang Lembur

Untuk memotivasi karyawan agar lebih meningkatkan produktivitas perusahaan telah menerapkan sistem pemberian uang lembur seperti yang telah dikemukakan pada bab terdahulu. Sistem pemberian uang lembur yang ditetapkan perusahaan cukup ketat sehingga karyawan harus berusaha mengoptimalkan kemampuannya untuk mendapatkan fasilitas tersebut, sementara karyawan yang memiliki sikap santai tetap kurang termotivasi.

c) Tunjangan Transportasi

Tunjangan transportasi yang diberikan oleh perusahaan kurang memotivasi karyawannya karena jumlahnya kurang mencukupi. Disamping itu karyawan yang belum satu tahun bekerja tidak mendapat tunjangan transport, tentu saja akan menimbulkan kesenjangan sosial. Dalam hal ini perusahaan dinilai kurang adil.

\section{d) Fasilitas Kesehatan}

Fasilitas kesehatan yang diberikan oleh perusahaan cukup memadai dan sehingga dapat memotivasi karyawannya. Dengan memberikan fasilitas pengobatan gratis akan lebih memotivasi karyawan untuk tetap setia dan loyal kepada perusahaan.

\section{Insentif Yang Diterima Karyawan}

Pelaksanaan pemberian motivasi positif dapat juga dilakukan dengan memberikan berbagai insentive antara lain dapat berupa :

\section{Material incentive}

\section{Non material incentive}

Material incentive, yaitu pemberian insentif atau premi atau perangsang yang dapat dinilai dengan uang. Uang merupakan suatu alat motivasi yang berguna untuk memuaskan kebutuhan ekonomi karyawan. Kalau kita bertanya kepada seseorang karyawan mengapa ia bekerja maka 
jawabannya yang sering diberikan adalah untuk mendapatkan uang. Pengguna uang sebagai alat motivasi terutama berguna untuk memuaskan kebutuhan yang bersifat physiologis.

Non material incentive, yaitu segala jenis perangsang atau insentif yang tidak dapat dinilai dengan uang. Umumya pemberian non material dapat berupa fasilitas yang diberikan kepada karyawan yang berprestasi. Hal ini dapat dilakukan dengan jalan:

a. Pemberian penghargaan terhadap pekerja yang dilakukan cara ini sering diabaikan sebagai alat motivasi yang sangat berguna dimana orang senang menerima pujian terhadap pekerjaan yang diselesaikan dengan baik.

b. Pemberian perhatian yang tulus kepada karyawan sebagai seorang individu car ini memang sukar dilakukan karena perhatian yang tulus tidak dapat dilakukan secara asal saja. Dalam hal ini pimpinan perlu berhati-hati dalam memberikan perhatian, ini sebabnya concept Individual Defferences, suatu perhatian yang diberikan bisa menimbulkan akibat yang berbeda terhadap orang yang berbeda.

c. Persaingan, pada umumnya orang senang bersaing secara jujur. Sikap dasar ini dapat dimanfaatkan oleh pimpinan dengan memberikan persaingan yang sehat dalam menjalankan pekerjaannya.

d. Partisipasi, turut sertanya setiap individu dalam pengambilan keputusan didalam perusahaan merupakan sumber daya perangsang yang tidak kurang pentingnya. Hal ini dapat dilihat dengan duduknya wakil-wakil karyawan dalam proses pengambilan keputusan dalam perusahaan. Hal ini merupakan suatu langkah untuk mengurangi salah pengertian disamping memajukan kerjasama antara pimpinan dengan pegawai sehingga timbul rasa tanggung jawab dan perhatian kepada perusahaan.

Selanjutnya kondisi pekerjaan yang menyenangkan akan memperbaiki moral karyawan dan kesungguhan bekerja. Peralatan yang baik, ruang pekerjaan yang nyaman, penerangan yang cukup bukan saja dapat menambah kegairahan kerja tetapi dapat juga menimbulkan efektivitas kerja.

Pemberian informasi kepada pegawai perusahaan tentang keadaan perusahaan merupakan suatu kebutuhan dari pegawai perusahaan. Pemberian informasi dapat diwujudkan dengan mengadakan pertemuan-pertemuan khusus melalui majalah perusahaan, pengiriman surat dan lain sebagainya. Tindakan semacam ini dapat menimbulkan saling pengertian antara atasan dengan bawahan. Dalam pemberian informasi harus dijelaskan kemajuan perusahaan, kesulitan yang dihadapi, proyek yang dilaksanakan dan sebagainya.

\section{Peranan Balas Jasa Terhadap Motivasi Kerja}

Didalam suatu perusahaan peranan balas jasa sangat besar. Hal ini dikarenakan balas jasa sangat menentukan kemajuan perusahaan tersebut. Apabila suatu perusahaan memberikan balas jasa yang besar kepada karyawan, maka para karyawan akan lebih giat dan bersemangat dalam bekerja sehingga akan menambah jumlah produksi dari perusahaan tersebut. Sehingga perusahaan tersebut bisa terus maju. Dan sebaliknya apabila perusahaan memberikan balas jasa yang relatif rendah kepada karyawan, maka para karyawan akan malas bekerja sehingga akan menimbulkan efek yang kurang baik terhadap perusahaan tersebut yaitu jumlah produksi perusahaan tersebut akan rendah.

Mengapa di beberapa perusahaan sering terjadi protes dalam bentuk demo para karyawan menuntut kenaikan gaji atau upah? Seolah tidak peduli dengan masalah krisis finansial global, para karyawan merasa berhak untuk menuntut kompensasi (insentif) sesuai dengan jasa yang sudah dikeluarkannya. Faktor yang menyebabkannya antara lain dalam hal ketidakpuasan tentang manajemen kompensasi yang diterapkan perusahaan. Manajemen kompensasi dinilai tidak memberikan efek pada kesejahteraan karyawan. Pada gilirannya motivasi karyawan menurun dan ini akan mengakibatkan produktifitas kerja atau kinerja mereka berada di bawah standar perusahaan.

Insentif mengandung arti tidak sekedar hanya dalam bentuk bentuk finansial saja. Bentuk finansial langsung berupa upah,gaji, komisi, dan bonus. Sementara yang tidak langsung berupa asuransi, bantuan sosial, uang cuti, uang pensiun, pelatihan, dan sebagainya. Selain itu bentuk bukan finansial berupa unsur-unsur jenis pekerjaan dan lingkungan pekerjaan. Bentuk unsur pekerjaan meliputi tanggung jawab, perhatian dan penghargaan dari pimpinan, sementara bentuk lingkungan pekerjaan berupa kenyamanan kondisi kerja, distribusi pembagian kerja, dan kebijakan perusahaan.

Keterkaitan insentif dengan kinerja karyawan sangatlah signifikan. Semakin tinggi kompensasi semakin tinggi tingkat kepuasan kerja karyawan; ceteris paribus. Derajat kepuasan yang semakin tinggi akan semakin meningkatkan motivasi karyawan dalam meraih kinerja yang tinggi. Jika dikelola dengan baik, kompensasi membantu perusahaan untuk mencapai tujuan dalam memperoleh, memelihara, dan menjaga karyawan dengan optimum. Sebaliknya tanpa kompensasi yang cukup, karyawan yang ada tidak saja mengekspresikan diri mereka dalam bentuk 
protes keras dan mogok kerja, tetapi juga sangat mungkin meninggalkan perusahaan. Pertanyaannya mengapa tidak semua perusahaan mampu memberikan kepuasaan maksimum kepada karyawannya?

Posisi insentif dalam membangun perusahaan yang sehat selalu berada pada kondisi yang rumit. Artinya jika dilihat dari besarannya hampir mungkin karyawan tidak pernah mengatakan manfaat kompensasi yang diterimanya sudah maksimum. Selalu dikatakan derajat kepuasaan yang diperolehnya sekedar dalam rentang kurang sampai cukup puas atau pas-pasan. Di sisi lain perusahaan tidak mudah untuk segera memenuhi kebutuhan karyawan yang semakin besar dan bervariasi. Persoalannya terletak pada pertimbangan penentuan kompensasi yang tidak sederhana dan mudah diputuskan. Penentuan besaran kompensasi sangat dipengaruhi kondisi internal dan eksternal perusahaan. Kondisi kesehatan finansial dan profitabiliti perusahaan sangat menentukan kemampuan perusahaan dalam memberi kompensasi yang layak. Selain itu juga sangat dipengaruhi oleh tekanan-tekanan luar seperti peraturan pemerintah, pasar kerja, pasar komoditi, krisis ekonomi global, dan tantangan kompensasi internasional.

Untuk menjembatani jurang antara kepentingan perusahaan di satu pihak dan pihak lain kepentingan karyawan maka perusahaan perlu menerapkan manajemen kompensasi yang layak. Maksudnya adalah untuk membantu perusahaan dalam mencapai tujuan strategi bisnisnya dan menjamin terjadinya keadilan kompensasi berbasis pertimbangan faktor-faktor internal dan eksternal. Keadilan internal menjamin bahwa permintaan posisi kompensasi (finansial dan non-finansial) seperti gaji dan upah serta kualifikasi seseorang dalam bidangnya yang lebih tinggi akan dipenuhi sesuai dengan perilaku dan kinerjanya. Dan ini tentunya juga dengan mempertimbangkan faktor eksternal yang menjamin bahwa pekerjaanpekerjaan bakal dikompensasi secara adil dengan membandingkannya dengan pekerjaan yang sama di pasar kerja.

Terpenuhinya kebutuhan fisik karyawan telah tercapai dengan sistem gaji dan upah yang adil dan wajar serta adanya insentif tambahan. Kompensasi tersebut dapat ditunjukkan antara lain sistem penggajian yang sesuai UMK, kenaikan gaji dan upah secara berkala,tunjangan masa kerja dan jabatan, pembayaran upah lembur, premi produksi dan potongan gaji. Adanya rasa aman dan keselamatan dalam bekerja telah tercapai dengan adanya tunjangan kesehatan, tunjangan kematian, jaminan hari tua, dan jaminan kecelakaan kerja. Terpenuhinya kebutuhan sosial telah tercapai dengan adanya koperasi simpan pinjam yang diadakan oleh pihak serikat pekerja dan adanya program rekreasi untuk seluruh karyawan, serta terjalinnya hubungan baik karyawan dilingkungan masyarakat. Terpenuhinya kebutuhan akan penghargaan/pengakuan dan kebutuhan akan perwujudan diri telah tercapai dengan adanya rasa saling menghormati antara atasan dan bawahan, adanya penghormatan yang lebih dikalangan masyarakatnya,adanya pelatihan untuk karyawan, adanya pertemuan untuk mengevaluasi kinerja serta menampung pendapat dari karyawan.

\section{Teknik Pengumpulan Data}

Teknik pengumpulan data yang digunakan adalah kuisioner. Kuisioner dilakukan dengan membagikan angket kepada responden yang berguna untuk mengetahui tanggapan mereka mengenai faktor - faktor yang mempengaruhi motivasi kerja. Kuisioner dibuat dalam bentuk pernyataan dengan mencantumkan beberapa pilihan jawaban dan responden hanya diperkenankan memilih salah satu jawaban yang paling tepat. Tujuan pokok pembuatan kuesioner adalah untuk memperoleh informasi yang relevan dengan masalah dan tujuan penelitian, dan untuk memperoleh informasi dengan reliabel dan validitas yang tinggi. Hal yang perlu diperhatikan oleh peneliti dalam menyusun kuesioner, pertanyaan-pertanyaan yang disusun harus sesuai dengan hipotesa dan tujuan penelitian.

Menurut Suharsimi Arikunto, sebelum kuesioner disusun memperhatikan prosedur sebagai berikut:

1) Merumuskan tujuan yang akan dicapai dengan kuesioner.

2) Mengidentifikasikan variabel yang akan dijadikan sasaran kuesioner.

3) Menjabarkan setiap variabel menjadi sub-sub variabel yang lebih spesifik dan tunggal.

4) Menentukan jenis data yang akan dikumpulkan, sekaligus unit analisisnya.

\section{Teknik Analisis Data \\ Analisis Data kualitatif}

Data yang diperoleh dari berbagai sumber dalam penelitian kualitatif dapat menggunakan teknik pengumpulan data yang bermacam-macam (triangulasi) dan dilakukan secara terus-menerus sampai datanya jenuh (dapat disimpulkan). Pengamatan yang terus-menerus menghasilkan variasi data yang tinggi. Oleh karena itu sering mengalami kesulitan dalam proses menganalisanya. Analisis data kualitatif adalah bersifat induktif, yaitu suatu analisis berdasarkan data yang diperoleh selanjutnya dikembangkan pola hubungan tertentu atau menjadi hipotesis. Berdasarkan hipotesis yang telah dirumuskan maka selanjutnya mencari data lagi secara terus-menerus agar dapat digeneralisasikan apakah hipotesis diterima atau ditolak berdasarkan data valid yang 
telah terkumpul. Ketika hipotesis diterima berdasarkan data yang terkumpul maka hipotesis dapat berkembang menjadi teori.

Proses analisis data dalam penelitian kualitatif pada teorinya dilakukan sejak sebelum memasuki lapangan, selama di lapangan dan setelah selesai di lapangan. Analisis data kualitatif seringkali berlangsung selama proses pengumpulan data daripada setelah selesai pengumpulan data.

\section{Analisis Data Kuantitatif}

Data perolehan dari pengumpulan data dalam penelitian pada hakikatnya adalah untuk menguji kebenaran suatu hipotesis atau setidaknya dapat menjawab pertanyaan penelitian. Akan tetapi yang perlu menjadi prinsip ialah data tersebut bukan data yang diada-adakan/non-real. Sebagaimana diketahui bahwa dalam penelitian kuantitatif maka alat untuk mengolah datanya yaitu dengan menggunakan statistik yang terbagi menjadi statistik deskriptif dan statistik inferensial

\section{KESIMPULAN DAN SARAN \\ Kesimpulan}

1. Sistem pemberian balas jasa dan insentif yang diberikan PT. Sony Gemerlang Medan sudah cukup baik. Sistem yang dilakukan telah memenuhi aspek-aspek tujuan, metode, asasasas, dan faktor-faktor yang mempengaruhi motivasi kerja karyawan.

2. Peranan balas jasa dan insentif yang dilakukan PT. Sony Gemerlang Medan sudah berjalan baik dan sesuai sehingga menunjang peningkatan motivasi kerja karyawan. Hal tersebut dapat di tinjau antara lain dari sisi ketercapaian hierarki kebutuhan yang menjadi sumber motivasi yaitu terpenuhinya kebutuhan fisik, adanya rasa aman, dan keselamatan dalam bekerja, terpenuhinya kebutuhan sosial, terpenuhinya kebutuhan akan penghargaan/ pengakuan dan kebutuhan akan perwujudan diri.

3. Faktor-faktor yang paling dominan berpengaruh terhadap motivasi kerja meliputi: insentif, kelelahan bekerja, status, uang transport, peraturan yang berlaku, tunjangan, kepuasan, kematangan pribadi, supervisi yang baik, penghargaan atas prestasi dan kelompok kerja.

\section{Saran}

Adapun saran yang diberikan kepada pihak manajemen adalah :

1. Sebaiknya perusahaan menambah insentif kepada karyawan yang berprestasi, memperhatikan lingkungan kerja, memperjelas status kepegawaian, menambah uang transport, peraturan yang berlaku, menambah jenis tunjangan, meningkatkan kepuasan karyawan, meningkatkan kematangan pribadi, menambah supervisi yang baik, penghargaan atas prestasi dan meningkatkan kerja sama antar kelompok kerja.

2. Fasilitas-fasilitas yang diberikan perusahaan untuk memotivasi karyawan hendaknya dapat dipertahankan dan lebih ditingkatkan sehingga karyawan merasa puas bekerja pada perusahaan.

3. Perusahaan hendaknya memberikan kesempatan kepada karyawan untuk turut memberikan ide maupun sebagaimana sebenarnya keinginan mereka dan kebutuhan mereka sehingga karyawan dengan senang hati mengoptimalkan produktivitasnya.

4. Karyawan hendaknya selalu menjaga kedisiplinan terutama masalah keterlambatan jam kerja yang akan berpengaruh pada pengurangan produksi perusahaan.

5. Karyawan hendaknya lebih mengembangkan prestasi dan produktivitas kerjanya dengan aktif mengikuti setiap pelatihan-pelatihan yang diadakan perusahaan supaya mendapat insentif yang lebih besar lagi.

\section{Referensi}

Arikunto,Suharsimi. Prosedur Penelitian: Suatu Pendekatan Praktek, Edisi Kelima, Jakarta : Rineka Cipta. 2006.

Daft, Richard L. Manajemen, Alih Bahasa: Elim Salim dan Iman Karmawan, Edisi Kelima, Jakarta: Erlangga. 2007

Hasibuan, Malayu. Manajemen Sumber Daya Manusia, Edisi Revisi, Cetakan Keenam, Jakarta: Bumi Aksara. 2006.

Mathis, Robert L dan Jackson John H. Manajemen Sumber Daya Manusia. Buku 2, Alih Bahasa: Sadeli dan Prawira Hle, Edisi Pertama, Jakarta: Salemba Empat. 2007.

Mangkunegara, Anwar Prabu. Evaluasi Kinerja Sumber Daya Manusia, Cetakan Pertama, Bandung: Aditama. 2006.

Papu, Johannes, Faktor-Faktor Yang Mempengaruhi Motivasi. Team epsikologi. 2007.

Rahayuningsih,DeasyAriyanti.Manajemen Usahawan Indonesia NO. 12 XXXV. Trisakti School Of Management. 2006. 
Saydam, Gouzali, Manajemen Sumber Daya Manusia: Suatu Pendekatan Mikro, Cetakan Ketiga, Jakarta: Djambatan. 2006.

Siagian P, Sondang, Manajemen Sumber Daya Manusia, Edisi Petama, Cetakan Kesembilan, Jakarta: Bumi Aksara. 2006.

Sinaga, D. (2018). PENGARUH DISIPLIN KERJA, KEMAMPUAN PERSONAL DAN GAYA KEPEMIMPINAN TERHADAP KINERJA KARYAWAN UNIVERSITAS DARMA AGUNG MEDAN. Jurnal Darma Agung, 26(1), 566-576. Retrieved from https://jurnal.darmaagung.ac.id/index.p $\underline{\mathrm{hp} / \text { jurnaluda/article/view/91 }}$

Sugiyono,Metode Penelitian Administrasi, Cetakan Ketujuh, Bandung: Alfabeta. 2007.

Ranupandojo, Heidjrahman, Manajemen Sumber Daya Manusia, Edisi Kedua, Cetakan Ketiga, Bandung: Aditama. 2006. 